
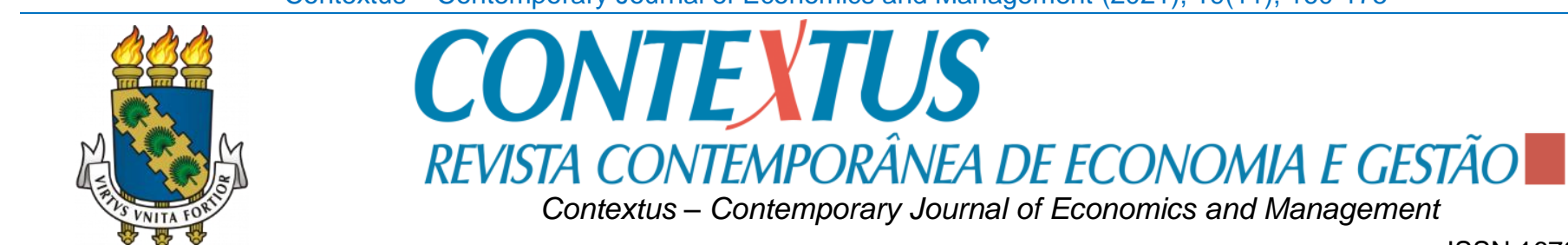

Contextus - Contemporary Journal of Economics and Management

FEDERAL UNIVERSITY

ISSN 1678-2089

OF CeArá

www.periodicos.ufc.br/contextus

\title{
Entrepreneurial ecosystem: Analysis of the contribution of universities in the creation of technology-based firms
}

\author{
Ecossistema empreendedor: Análise da contribuição de universidades na criação de empresas de \\ base tecnológica
Ecosistema emprendedor: Análisis de la contribución de las universidades en la creación de empresas de base tecnológica

https://doi.org/10.19094/contextus.2021.68011 d

\section{João Paulo Moreira Silva}

https://orcid.org/0000-0002-9470-2905 (D) PhD student at Post-Graduate Program in Management at the Pontifical Catholic University of Minas Gerais

Master in Management at the Pontifical Catholic University of Minas Gerais

joao.msilva@live.com

\section{Liliane de Oliveira Guimarães}

https://orcid.org/0000-0002-3346-2207 (D)

Professor at Post-Graduate Program in Management at the Pontifical Catholic University of Minas Gerais

$\mathrm{PhD}$ in Business Administration from the Fundação Getulio Vargas - São Paulo School of Business Administration

lilianeog@pucminas.br

\section{Edmundo Inácio Júnior}

https://orcid.org/0000-0003-0137-0778 (D) Professor at School of Applied Sciences in the University of Campinas

$\mathrm{PhD}$ in Business Administration from the School of Applied Sciences in The University of Campinas

edmundo.inacio@fca.unicamp.br

\section{José Márcio de Castro}

https://orcid.org/0000-0002-3170-9456 (D)

Professor at Post-Graduate Program in Management at the Pontifical Catholic University of Minas Gerais

$\mathrm{PhD}$ in Business Administration from the University of São Paulo

josemarcio@pucminas.br

\section{Article Information}

Uploaded on 25 March 2021

Final version on 11 May 2021

Accepted on 13 May 2021

Published online on 31 May 2021

Interinstitutional Scientific Committee Editor-in-chief: Diego de Queiroz Machado Evaluation by the double blind review system (SEER / OJS - version 3)

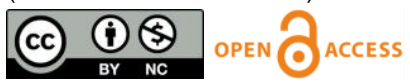

\section{ABSTRACT}

This paper aimed to analyze how higher education institutions contribute to the creation of technology-based firms. The research method was that of multiple cases, represented by two universities and five technology-based firms in Belo Horizonte. We selected businesses that had as founders students or former students of the researched universities. The results showed that the institutions have robust structures and programs, but still act in a little internally integrated way. In addition, the entrepreneurs do not identify the contribution of their university education in their entrepreneurial trajectory. The study contributes to the understanding of the role of the university in the entrepreneurial ecosystem. From a theoretical point of view, the study identified categories of analysis to evaluate entrepreneurial universities.

Keywords: entrepreneurship; entrepreneurial ecosystem; technology-based firms; universities; multiple cases.

\section{RESUMO}

Este artigo teve por objetivo analisar como as instituições de ensino superior contribuem na criação de empresas de base tecnológica. O método de pesquisa foi o de casos múltiplos, representados por duas universidades e cinco empresas de base tecnológica de Belo Horizonte. Foram selecionados negócios que tivessem como fundador aluno ou ex-aluno das universidades pesquisadas. Os resultados mostraram que as instituições apresentam estruturas e programas robustos, mas ainda atuam de forma pouco integrada internamente. Além disso, os empresários não identificam contribuição da sua formação universitária na sua trajetória empreendedora. O estudo contribui para a compreensão do papel da universidade no ecossistema empreendedor. Do ponto de vista teórico, o estudo identificou categorias de análise para se avaliar universidades empreendedoras.

Palavras-chave: empreendedorismo; ecossistema empreendedor; empresas de base tecnológica; universidades; casos múltiplos.

\section{RESUMEN}

Este artículo pretende analizar cómo las instituciones de enseñanza superior contribuyen a la creación de empresas de base tecnológica. El método de investigación fue el de casos múltiples, representados por dos universidades y cinco empresas de base tecnológica de Belo Horizonte. Se seleccionaron empresas que tenían como fundador a un estudiante o ex estudiante de las universidades investigadas. Los resultados mostraron que las instituciones presentan estructuras y programas sólidos, pero siguen actuando de forma poco integrada internamente. Además, los empresarios no identifican la contribución de su formación universitaria en su trayectoria empresarial. El estudio contribuye a comprender el papel de la universidad en el ecosistema empresarial. Desde el punto de vista teórico, el estudio identificó categorías de análisis para evaluar las universidades emprendedoras.

Palabras clave: emprendimiento; ecosistema empreendedor; empresas de base tecnológica; universidades; casos múltiples.

How to cite this article:

Silva, J. P. M., Guimarães, L. O., Inácio, E., Jr., \& Castro, J. M. (2021). Entrepreneurial Ecosystem: Analysis of the contribution of universities in the creation of technologybased firms. Contextus - Contemporary Journal of Economics and Management, 19(11), 160-175. https://doi.org/10.19094/contextus.2021.68011 


\section{INTRODUCTION}

Discussions on the creation of ventures based on new technologies have brought to the surface new strands of research. One of these strands analyzes entrepreneurial activity based on the articulation, stimulation, and support of elements or actors, in what is called the entrepreneurial ecosystem (Isenberg, 2011; Mason \& Brown, 2014).

Including topics such as regional development and strategy (Acs et al., 2017), the study on entrepreneurial ecosystems emphasizes issues such as the influence of the local environment for the generation of new ventures, the interactions between the various actors that compose it, and a special attention to fast-growing companies (Mason \& Brown, 2014). However, it should be noted that, although the growth of the literature on the topic is perceived (Borissenko \& Boschma, 2017), and the transformation of the topic into a trend (Brown \& Mason, 2017), gaps remain in the theoretical development of the field. One can cite the lack of studies that emphasize the causal relationships between the actors present in the ecosystem (Borissenko \& Boschma, 2017; Isenberg, 2011), the need for more studies that identify conditions for the formation of successful ecosystems (Mack \& Mayer, 2015), and for more studies in local contexts, such as cities (Audretsch \& Belitski, 2017) and in emerging economies (Cao \& Shi, 2020).

One of the actors that have gained relevance in the entrepreneurial ecosystem in recent years is the university, due to its contribution to the generation of knowledge, development of new technologies, generation of new ventures, and subsequent return to society by contributing to economic and social development (Foster \& Shimizu, 2013; Fritsch \& Wyrwich, 2018; Global Entrepreneurship Index [GEI], 2017). Universities are then expected to contribute to the generation of innovative ventures (Dahlstrand, 2007; Ganotakis, 2012). However, the role of universities and the relationships with the other actors in the entrepreneurial ecosystem are unclear and lack more robust explanations (Guerrero \& Urbano, 2017; Neumeyer et al., 2019). Considering this context, we set the following research question: how do higher education institutions $\mathrm{HEI}$ influence and contribute to the creation and development of technology-based firms - TBF?

The research results contribute and help in understanding the relationships between HEI and TBF. In the case studied, it was possible to recognize that universities have an incipient role in the development of technology-based firms. Despite having a robust infrastructure and a considerable number of programs to foster entrepreneurial activity, the actions of the HEI were supplanted by those of external actors of the local ecosystem - private actors - as to the supply of resources, such as knowledge in management. Also as a contribution of the study, was identified that HEl should expand the dissemination of their resources aimed at fostering entrepreneurial activity, so as to make them recognized actors with a greater impact on the ecosystem.

The article is structured in five more sections, in addition to this introduction. In section 2, we present the theoretical framework that supported the creation of a research model and its dimensions. In section 3, we describe the main methodological steps used to collect and analyze the data, which involved mapping the structures of the HEI that support and foster entrepreneurship, the actions developed by these $\mathrm{HEl}$ to strengthen the entrepreneurial culture in the ecosystem, and the actions taken by the HEI that contributed to the creation of TBF, from the perspective of the entrepreneurs. In section 4, we present the data analysis and discussion. Finally, in section 5 , the main conclusions and suggestions for future work are established.

\section{THEORETICAL FRAMEWORK}

\subsection{Entrepreneurship and entrepreneurial ecosystem}

Since the beginning of the 20th century, economic literature has discussed the relationship between organizations and the regions in which they are established (Isenberg, 2011; Maskel \& Kebir, 2009). Initially, companies would gain an advantage through physical proximity to similar ones, such as cost advantages, availability of labor and knowledge spillovers (Marshall, 1985).

By relating the environment to the entrepreneurial activity, it is possible to identify elements that enable the installation and multiplication of organizations in a given region. Such environment can be recognized as "(...) a combination of factors that play a role in the development of entrepreneurship", such as (i) government policies; (ii) socioeconomic conditions; (iii) entrepreneurial and business skills; (iv) financial support and (v) non-financial support (Gnyawali \& Fogel, 1994, p.44). Still according to Gnyawali and Fogel (1994), other factors of individual character - in line with the environment - would make possible the creation of new companies, such as entrepreneurial and management skills, conditions that the authors call entrepreneurial ability.

Isenberg (2011), like Gnyawali and Fogel (1994) also recognizes in the so-called entrepreneurial ecosystems a viable strategy to stimulate economic prosperity through the integrated action of different actors. These actors or domains, in the Isenberg (2011) nomenclature - Markets, Public Policies, Financial Capital, Culture, Support Institutions and Human Resources - linked formally or informally to fast-growing organizations may lead to the economic development of a certain region (Isenberg, 2011; Mason \& Brown, 2014; Brown \& Mason, 2017).

Although the relative diffusion of the model proposed by Isenberg (2011), it was not the object of empirical studies that could, in practice, validate the relationship between the different domains and their consequences on the 
environment to which they are linked (Borissenko \& Boschma, 2017; Mack \& Mayer, 2015). In addition, their model does not take into account evidence collected directly from entrepreneurs (Foster \& Shimizu, 2013).

Seeking to remedy an aspect missing from the Isenberg (2011) model - understanding entrepreneurs' perceptions of the importance of ecosystem actors' support - Foster and Shimizu (2013) have developed a model of analysis that considers an entrepreneurial ecosystem to be supported by eight main pillars: (i) accessible markets; (ii) human capital workforce; (iii) financing; (iv) mentors, advisors and support systems; (v) regulatory model and infrastructure; (vi) education and training; (vii) large universities as catalysts and, finally, (viii) cultural support.
The three main pillars would be accessible markets, the workforce, and sources of funding.

From a comparison between the components of the entrepreneurial ecosystems cited, it can be seen the correspondence between the most current models and the greater presence of direct mention to environmental factors - inclusion of the market and human capital - and mention of universities and research institutes (Gnyawali \& Fogel, 1994; Isenberg, 2011; Foster \& Shimizu, 2013; GEI, 2017). Table 1 presents the domains present in the three entrepreneurial ecosystem models discussed and their components.

Table 1

Comparison between Entrepreneur Ecosystem models and their domains

\begin{tabular}{clll}
\hline Domains & Gnyawali and Fogel (1994) & \multicolumn{1}{c}{ Isenberg (2011) } & \multicolumn{1}{c}{ Foster and Shimizu (2013) } \\
\hline Public policies & Legislation that eases and promotes & Leadership: unequivocal support & Access to basic infrastructure and \\
& entrepreneurship. & based on legitimacy. Government: telecommunications. Tax incentives \\
institutions and facilitating regulatory & and facilitating legislation.
\end{tabular}
structure. Financial support and research institutes.

$\begin{array}{ll}\text { Finance } & \begin{array}{c}\text { Access to venture capital, alternative } \\ \text { sources of funding and low-cost } \\ \text { lending. }\end{array} \\ \begin{array}{l}\text { Culture and } \\ \text { Diversity of economic activity and } \\ \text { entrepreneurial attitude of society. }\end{array}\end{array}$

Supporting Institutions

Infrastructure, business networks and mentoring and government support services for R\&D for small businesses

Human Capital Technical, vocational and business education. Training programs on the subject and availability of information

Markets

Education and

training
Access to venture capital, micro loans and capital markets, angel investors, friends and family.

Success stories: visibility of success cases, wealth generation and reputation to founders.

Society norms: tolerance to risks and failures.

ING's: entrepreneurship in NGOs; support associations and competitions. Existence of professions and infrastructure support

Manpower: trained and untrained; serial entrepreneurs.

Educational institutions: diplomas (professional and academic) and specific training for the topic

Initial customers: early adopters to prove the concept; access to first comments and distribution channels.

Networks: networks of entrepreneurs and multinational corporations.
Access to risk capital and debt. Participation of angel investors, friends and family.

Tolerance to risk and failures success stories and positive image of entrepreneurship.

Culture of research and celebration of innovation. Preference for selfemployment.

Mentors and counselors; incubators and accelerators.

Professional services and networks of business partners.

Experience in entrepreneuria organizations; outsourcing and immigrant labor force. Technical and management talent.

Domestic market: government, large, small and medium enterprises as clients.

Foreign market: government, large, small and medium enterprises as clients.

Workforce available with preuniversity and university education. Large universities promoting entrepreneurial culture.

Source: adapted from Gnyawali and Foster (1994), Isenberg (2011) and Foster and Shimizu (2013).

\subsection{Entrepreneurial Universities}

As pointed out, the university plays an important role in promoting entrepreneurship (Schubert \& Kroll, 2016) and it is considered one of the central elements of Entrepreneurship Ecosystems (Spigel, 2015). The reason for this is that the university is inserted in a dynamic context with other actors, forming a system capable of jointly promoting technological, economic and social development (Ruiz \& Martens, 2019). The generation of knowledge and the creation of mechanisms for its transfer has elevated the university to a prominent role in the development of territories, redefining its traditional objectives - teaching and research - and emphasizing its mission as a trainer of intellectual, human and social capital, in favor of the development of regions (Clark, 2001; Etzkowitz \& Zhou, 2017; Fritsch \& Wyrwich, 2018).

Based on this new mission, research conducted at universities would not only be guided by academic objectives, but would also solve problems and solve market demands (Etzkowitz, 2004). In this way, the greater 
proximity between universities and companies would enrich the possibility of new research and project testing, stimulating new technology-based business (Plonski, 1999). As a consequence, the formation of new companies became the objective of universities, as well as the commercialization and technology transfer (Etzkowitz, 2004). The premise of the university as a generator of innovations, new industries, and companies is part of the triple helix approach (Etzkowitz \& Zhou, 2017; Leydesdorff, 2000). Collaborations in the triple helix format allow organizations to access new knowledge and technologies that can be used during the entrepreneurial process, generating incremental and radical innovations (Guerrero \& Urbano, 2017).

Following the steps of this change, support for academic and entrepreneurial actions has grown in the last decade, attracting the attention of several government agents in an attempt to encourage partnerships to raise levels of innovation (Etzkowitz, 2004; Etzkowitz, 2016; Thomas \& Pugh, 2020; Tornatzky \& Rideout, 2014), but without making them subject to industry or a "general purpose shopping center" (Clark, 2001, p. 10). Recent discussions point to the need for the university to interact with other actors, such as civil society, and to promote causes of common interest, such as those related to environmental preservation, which would integrate the fourth and fifth helix of an innovation system, respectively (Carayannis \& Rakhmatullin, 2014; Mineiro et al., 2018). The expansion of the role and mission of the university aims at the development of innovations that are pertinent to users - civil society - and includes the university in actions and efforts of a socio-environmental nature, aiming to contribute to the promotion of sustainable development (Carayannis \& Rakhmatullin, 2014). Concerns about the role of the university as an agent of regional development seek to highlight it as having a key role in promoting innovation and entrepreneurship, as well as in the interaction with the community and in efforts to preserve the environment, a fact that characterizes an Engaged University at the regional level (Thomas \& Pugh, 2020).

In these terms, the - Entrepreneurial University - EU can be defined as "(...) an academic structure and function that is reviewed by aligning economic development with research and teaching as academic missions" (Etzkowitz et al., 2000, p.314). Typical examples of entrepreneurial action are patenting and licensing, spin-off formation and the creation of technology parks (Phillpott et al., 2011; Torres et al., 2017). However, it should be noted that the entrepreneurial university should not only serve to generate new business in science and technology, but should also invest efforts to build entrepreneurship and entrepreneurial mindsets as one of its pillars (Clark, 2001; Phillpott et al., 2011), contributing to a more vibrant university environment (Ribeiro et al., 2018).

The core features of the EU would be: (i) capitalization - the knowledge generated becomes the basis for academic and institutional development processes; (ii) interdependence, based on close interaction with industry and government; (iii) independence, meaning that the university is not dependent on other institutions; (iv) hybridization, characteristic of hybrid organizations, being at the same time independent and interdependent, and finally; (v) reflectivity, a continuous renewal of the internal structure of the university as its relationships with other actors change (Etzkowitz, 2004).

However, this is not the only model for entrepreneurial universities highlighted by literature - for a systematization of possible entrepreneurial university models, we suggest Ruiz and Martens (2019). The changes evidenced by Clark (2006) in a second model are not oneoff, minor changes in teaching or research, but structural and cultural changes that add substantial value to the institution. The elements of this change are: (i) diversified income adding to the university the possibility of "restoring a loss here, with a gain there" (Clark, 2001, p.12), expanding its sources of income; (ii) strengthened administration capacity, from a central management that, allied to the academic departments, creates collective entrepreneurial activities; (iii) strong insertion in the surroundings; (iv) motivated academic nucleus that stimulates the entrepreneurial culture throughout the organization and, finally, (v) integrated entrepreneurial culture, with entrepreneurial activities going through teaching activities until the creation of new companies (Clark, 2006).

A third model that contemplates the transformations and processes necessary for universities to be characterized as entrepreneurs is suggested by Tornatzy and Rideout (2014). Among the five challenges cited by the authors that universities must overcome are: (i) objectives and aspirations; (ii) leadership, in which integrated departments and sectors develop activities to foster entrepreneurship and innovation; (iii) broadening of university boundaries, generally understood as the search for strategies that direct the innovation process towards entrepreneurial activities that positively impact society; (iv) partnerships with industry and community and (v) technology transfer.

In an effort to systematize and integrate the key elements of the three approaches - Etzkowitz (2004), Clark (2001; 2006), and Tornatzky and Rideout (2014) - Figure 1 highlights the interactions between the elements of these approaches needed for the conversion of a traditional university into an entrepreneurial university. The Venn diagram allows the visualization of these dimensions, classified by the study, as similar or common among the three different proposals.

At the center of Figure 1 are the close and dynamic relationships between industry, government, and the university, as proposed by the triple-helix model (Etzkowitz \& Leydesdorff, 2000). 


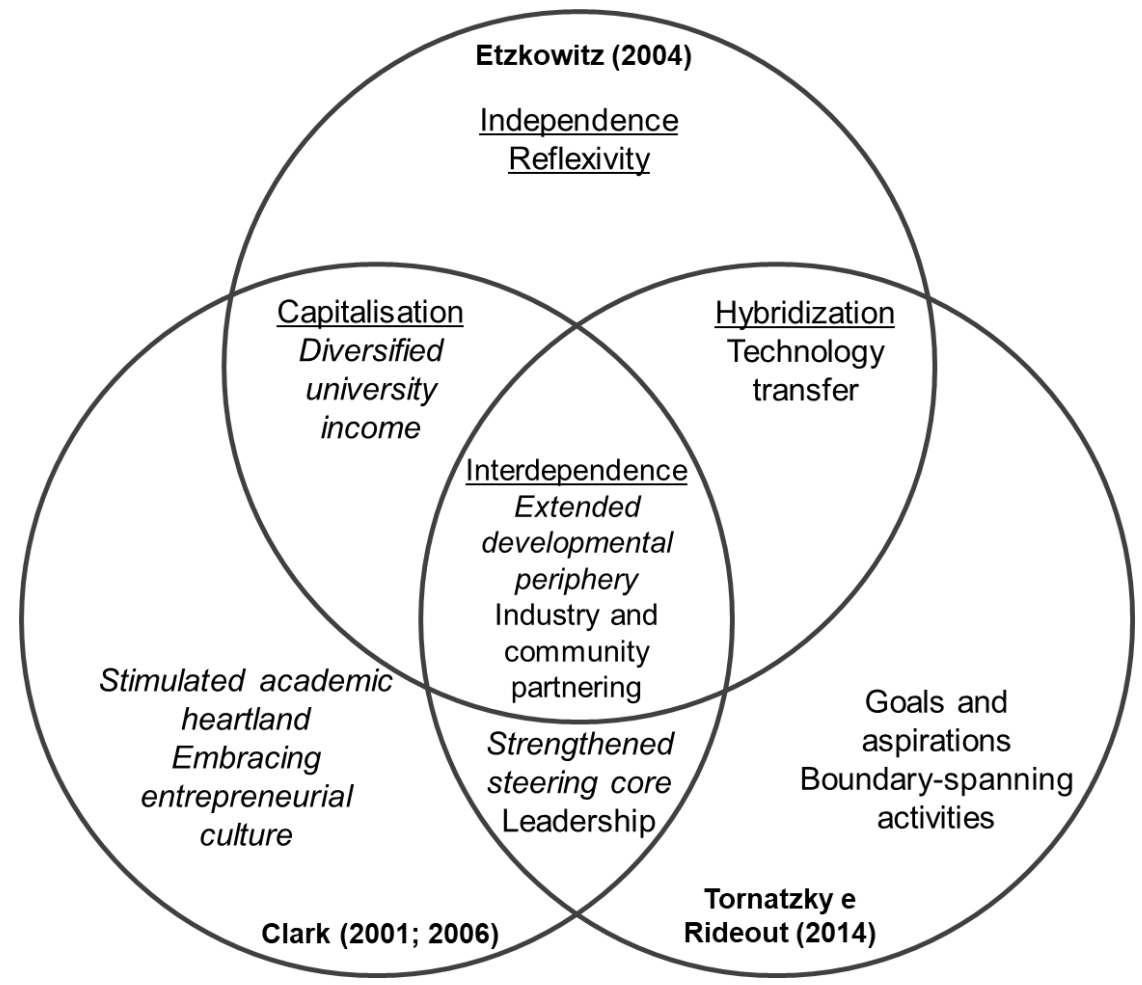

Figure 1. Integrated view of the elements that make up the entrepreneurial university.

Source: adapted by the authors from Clark (2001; 2006); Etzkowitz (2004) and Tornatzky and Rideout (2014).

\subsection{Theoretical model}

The literature review on entrepreneurial ecosystems and entrepreneurial universities made it possible to develop the theoretical model that guided the data collection and analysis. In this work, the model elaborated sought the integration of the three entrepreneurial ecosystem models mentioned above, proposed by Gnyawali and Fogel (1994), Isenberg (2011) and Foster and Shimizu (2013).

Initially, the theoretical model starts from the Human Capital domain of Isenberg (2011), where the Educational Institutions would be located. Later, it uses the entrepreneurial ecosystem model that highlights the presence of a specific domain referring to universities and their role in the ecosystem, in addition to having been developed jointly with entrepreneurs (Foster \& Shimizu, 2013).

Considering the objectives of the work and the areas mentioned by Foster and Shimizu (2013), three categories of analysis were defined: (i) Physical Structure, physical structures of universities that can support entrepreneurs in their trajectory, such as incubators, accelerators, coworkings, study rooms and extension; (Etzkowitz, 2004; Arruda et al., 2015; Inácio et al., 2016); (ii) Technical Support, such as education and training activities in entrepreneurship of a curricular or extra curricular nature (Etzkowitz et al, 2000; Dahlstrand, 2007; Tornatzky \& Rideout, 2014; Inácio et al., 2016) and (iii) Specialized Support - performance of mentors, consultants, participation in events or lectures that provide extra-class support to entrepreneurs and university graduates (Plonski 1999;
Etzkowitz, 2004; Tornatzky \& Rideout, 2014; Inácio et al., 2016).

\section{Table 2}

Categories defined to compose the theoretical model

\begin{tabular}{|c|c|c|}
\hline Categories & Examples & Authors \\
\hline $\begin{array}{l}\text { Physical } \\
\text { Structure }\end{array}$ & $\begin{array}{lr}\text { Incubators, } & \\
\text { accelerators, } & \text { co- } \\
\text { workings, study } \\
\text { rooms } \\
\text { extension }\end{array}$ & $\begin{array}{l}\text { Etkowitz (2004); Arruda, } \\
\text { Nogueira, Cozzi and } \\
\text { Costa (2015); Spigel } \\
\text { (2015); Inácio Júnior, } \\
\text { Autio, Morini, Gimenez } \\
\text { and Dionísio (2016); } \\
\text { Etzkowitz and Zhou, } \\
\text { (2017). }\end{array}$ \\
\hline $\begin{array}{l}\text { Technical } \\
\text { Support }\end{array}$ & $\begin{array}{l}\text { Education and } \\
\text { training activities in } \\
\text { entrepreneurship } \\
\text { (curricular or extra } \\
\text { curricular nature) }\end{array}$ & $\begin{array}{l}\text { Etkowitz, Webster, } \\
\text { Gebhardt and Terra } \\
\text { (2000); Dahlstrand (2007); } \\
\text { Tornatzky and Rideout } \\
\text { (2014); Inácio Júnior, } \\
\text { Autio, Morini, Gimenez } \\
\text { and Dionísio (2016); } \\
\text { Ribeiro, Uechi and Plonski } \\
\text { (2018). }\end{array}$ \\
\hline $\begin{array}{l}\text { Specialized } \\
\text { Support }\end{array}$ & $\begin{array}{l}\text { Events, lectures, } \\
\text { competitions, } \\
\text { consultants, } \\
\text { mentoring }\end{array}$ & $\begin{array}{l}\text { Plonski (1999); Etkowitz } \\
\text { (2004); Tornatzky and } \\
\text { Rideout (2014); Spigel } \\
\text { (2015); Inácio Júnior, } \\
\text { Autio, Morini, Gimenez } \\
\text { and Dionísio, (2016); } \\
\text { Ribeiro, Uechi and Plonski } \\
\text { (2018) }\end{array}$ \\
\hline
\end{tabular}

Source: elaborated by the authors.

The assumption is that the presence and performance of these three elements would have a positive effect on students, facilitating the acquisition and development of entrepreneurial and management skills (Gnyawali \& Fogel, 1994). This would result in higher rates 
of new business creation. Figure 2 illustrates the theoretical model used for data analysis.

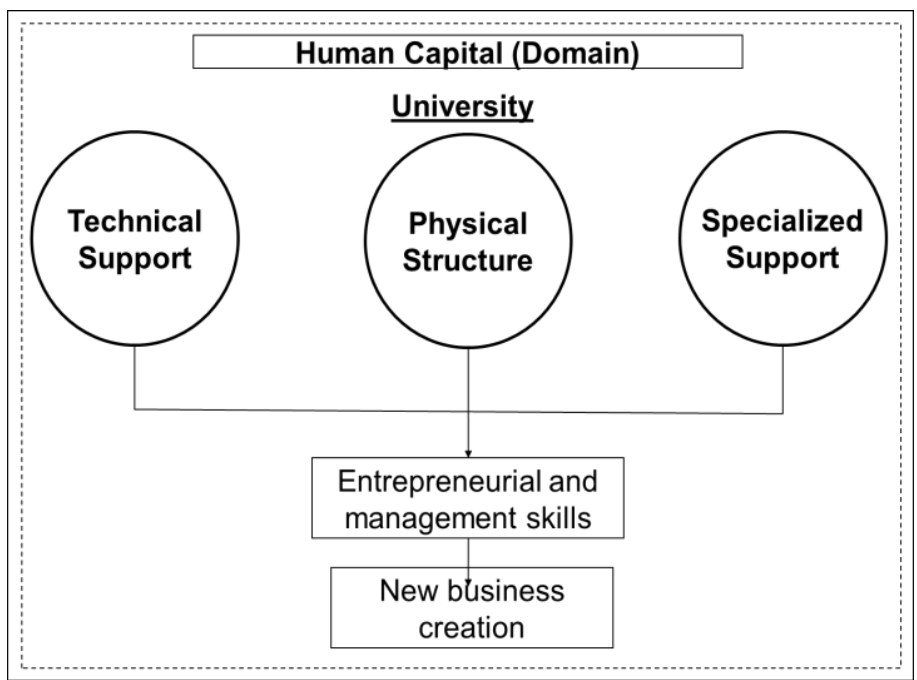

Figure 2. Theoretical model used.

Source: elaborated by the authors.

\section{METHODOLOGY}

The approach used in the research was of a qualitative nature. As for the method, the format chosen was the descriptive case study. A case study can be defined as an analysis of specific social phenomena, at a specific time and location (Ragin \& Becker, 1992; Suddaby et al., 2015).

As underlined in the introduction of this article, the objective was to understand, in a more detailed way, the influence of higher education institutions in the decision to undertake from the point of view of technology-based entrepreneurs in Belo Horizonte. This phenomenon, considering the different agents - educational institutions, support and development actors, entrepreneurial individuals and the academic community - is too complex and full of particularities to be analyzed from a quantitative approach. Moreover, understanding the context in which such actors are immersed is part of the study, thus justifying the use of case studies (Yin, 2010).

Multiple cases were used, represented by the network of relations that links the university and some technology-based firms in Belo Horizonte. The technologybased businesses established in Belo Horizonte were selected, which had as their entrepreneur partner a former student from the aforementioned public and private universities located in Belo Horizonte, or a student who had some kind of usufructuary relationship with the university's entrepreneurship support facilities. The choice of the two cases, in different contexts, enables comparison and ultimately provides more robust and convincing data (Yin, 2010).

In each of the university institutions selected for the research, technology-based firms that were within the scope initially developed for the research were examined. Among the five companies studied, three were founded by former undergraduate students of the universities and two by entrepreneurs who were still undergraduate.

After selecting the cases, the next task was to establish the data collection sources. The in-depth interview (Gaskell, 2003; Eisenhardt \& Grabner, 2007), observation (Eisenhard, 1989; Yin, 2010), as well as relevant documents and archives (Yin, 2010) were selected. Multiple data sources allow convergent analysis and, later, the certification of survey data saturation (Fusch \& Ness, 2015). The first step for data collection was the preparation of the interview script which was based on the literature review and whose script considered three thematic axes: (i) technical support, (ii) physical structure; and (iii) specialized support, as established in the theoretical model. Table 3 presents the list of interviewees in data collection.

Table 3

List of interviews conducted during the survey

\begin{tabular}{lll}
\hline Interviews & Interviewed & $\begin{array}{l}\text { Duration } \\
\text { Time }\end{array}$ \\
\hline Interview 01 & Entrepreneur - Delta Company & 01:40:00 \\
Interview 02 & Coordinator - Program 1 & 00:58:00 \\
\hline Interview 03 & Entrepreneur - Alfa Company & $01: 40: 00$ \\
Interview 04 & Coordinator - Program 2 & $01: 20: 00$ \\
Interview 05 & Entrepreneur - Beta Company & $01: 18: 00$ \\
Interview 06 & Coordinator - Program 3 & $00: 51: 00$ \\
\hline Interview 07 & Entrepreneur - Gamma Company & 00:45:00 \\
Interview 08 & Coordinator - Structure 1 & $00: 32: 00$ \\
\hline Interview 09 & Entrepreneur - Sigma Company & $00: 53: 00$ \\
Interview 10 & Coordinator - Structure 2 & $01: 36: 00$ \\
\hline Interview 11 & Coordinator - Structure 3 & $00: 57: 00$ \\
Interview 12 & Coordinator - Program 4 & $01: 43: 00$ \\
\hline
\end{tabular}

Source: elaborated by the authors.

In addition to the interviews, a total of six documents and archives were identified and selected, relating to the private university and thirteen at the public university. In each of the documents and archives there was the concern to obtain and classify the complementary information according to the types of support from the universities (technical support, physical structure, specialized support) as they can be seen in Table 4. Among the documents were advertising texts, ordinances, notices and calls/calls for university programs to promote entrepreneurship and innovation, as well as reports on activities resulting from these programs.

The data collection allowed, from the content analysis, to constitute a considerable corpus of research (Bardin, 2011), composed of 12 in-depth interviews recorded and transcribed, in addition to the documents and files collected totaling 280 pages.

For this research, the analysis started from a thematic perspective, more specifically, categorical content analysis (Bardin, 2011), qualitative and transversal, using interview clippings, documents and archives - physical structure, technical support and specialized support. Later, such categories were also used in the coding analysis conducted through Nvivo software, versions 10 and 11. 


\section{Table 4}

List of documents used during the search

\begin{tabular}{|c|c|c|c|c|c|}
\hline Document & Description & University & $\begin{array}{l}\text { Technical } \\
\text { Support }\end{array}$ & $\begin{array}{l}\text { Physical } \\
\text { Structure }\end{array}$ & $\begin{array}{l}\text { Specialized } \\
\text { Support }\end{array}$ \\
\hline Doc. 01 & Institutional - Program 1 & Private & $\mathrm{X}$ & $\mathrm{X}$ & \\
\hline Doc. 02 & Internal Ordinance - NIT & Private & & $\mathrm{X}$ & $\mathrm{X}$ \\
\hline Doc. 03 & Institutional & Private & $X$ & & \\
\hline Doc. 04 & Institutional (trajectory and history) & Private & $X$ & $X$ & \\
\hline Doc. 05 & Institutional (course catalog) & Private & $X$ & & \\
\hline Doc. 06 & Institutional - Innovation Hub & Private & & $\mathrm{X}$ & $\mathrm{X}$ \\
\hline Doc. 07 & Internal Interview - NIT & Public & & $X$ & \\
\hline Doc. 08 & Institutional - Technology Park & Public & & $X$ & $\mathrm{X}$ \\
\hline Doc. 09 & Institutional (inauguration) - Technology Park & Public & & $X$ & \\
\hline Doc. 10 & Internal Release & Public & $X$ & $X$ & \\
\hline Doc. 11 & Activity Report - NIT & Public & & $\mathrm{X}$ & $\mathrm{X}$ \\
\hline Doc. 12 & Institutional - NIT & Public & & $X$ & \\
\hline Doc. 13 & Internal Release & Public & & $X$ & $\mathrm{X}$ \\
\hline Doc. 14 & Institutional - Program 04 & Public & & & $\mathrm{X}$ \\
\hline Doc. 15 & Internal Release & Public & & & $\mathrm{X}$ \\
\hline Doc. 16 & Internal Release & Public & & & $\mathrm{X}$ \\
\hline Doc. 17 & Internal resolution (statute) & Public & $X$ & $X$ & \\
\hline Doc. 18 & Institutional & Public & $X$ & $X$ & $\mathrm{X}$ \\
\hline Doc. 19 & Institutional (data and numbers) & Public & & $\mathrm{X}$ & $\mathrm{X}$ \\
\hline
\end{tabular}

Source: elaborated by the authors.

\section{ANALYSIS AND DISCUSSION OF RESULTS}

In Brazil, studies demonstrate the existence of an entrepreneurial ecosystem, but with modest results when compared to those of developed nations, or even to the other components of the BRICS (Russia, India, China and South Africa) (Foster \& Shimizu, 2013; Inácio et al., 2016). It is noteworthy that, in general, entrepreneurial ecosystems present in developing economies are recognized for their shortcomings, such as scarcity of resources and structural gaps (Cao \& Shi, 2020). When analyzing Latin America, Foster and Shimizu (2013) pointed out shortcomings in accessible markets, funding sources, education and training, large universities as catalysts and cultural support.

Even positive indicators tend to be controversial, as the factor that analyzes the skills needed to start a new business. Although Brazilians, individually, claim to have the necessary skills to undertake, the country presents a bottleneck in relation to the levels of technical and higher education, in addition to low levels of enrollment in universities and technical schools (Inácio et al., 2016). This scenario points to a mismatch between university-generated knowledge, entrepreneurial activity and the market (Arruda et al., 2015; Inácio et al., 2016; Volles et al., 2017). Data from SEBRAE (Support Service for Micro and Small Enterprises), for example, show the presence of entrepreneurial training courses during graduation in only $28.4 \%$ of Brazilian universities (SEBRAE, 2016). On the other hand, universities stand out as incubator maintainers in the country, accounting for $61 \%$ of all incubators (National Association of Innovative Enterprise Promoting Entities [ANPROTEC], 2019).

The lack of integration between universities, government and industry implies a low rate of nascent companies that have rapid growth, since individuals are not able to conceive and implement businesses of this nature, which contributes to the still unexplored potential of entrepreneurship in national economic development (Global Entrepreneurship Monitor [GEM], 2019; Inácio et al., 2016).

To better use the data collected, the cases will be presented initially individually, and later compared, allowing a greater understanding of the investigation, confronting the relationships between institutions and the enterprises of students and alumni, reaching the conclusions of cross cases (Yin, 2010).

\subsection{Case 1 - Private University}

\subsubsection{Description of the case 1}

The private institution object of this research is considered one of the best private universities in Brazil and the largest Catholic university in the world. The institution has more than 56 thousand students, approximately 2,000 professors and the same number of employees assigned to eight campuses in several cities of the state of Minas Gerais (Document 04). The university has some indicators that attest to its excellence, such as the index of 3.02 in Innovation - driven by studies published in partnership with companies - and 20.01 in Research, placing the university in the 23rd and 101st positions, respectively, in the aforementioned items in the RUF - University Ranking Folha do ano de 2018.

The programs to promote innovation and entrepreneurship at the Private University are recent, having on average four years of existence. The Innovation Center is the only program to exhibit an integral partnership with an external company and with 10 years of operation. Table 5 below demonstrates the programs and structure found at the private university. 
Table 5

Programs and structures to support and foster entrepreneurship mapped at the private university

\begin{tabular}{llll}
\hline Programs & Beginning of activities & $\begin{array}{l}\text { Number of teachers working } \\
\text { directly }\end{array}$ & Classification \\
\hline Program 1 (P1) & 2009 & 5 & Innovation Center \\
Program 2 (P2) & 2014 & 5 & Pre-incubator \\
Program 3 (P3) & 2015 & 19 & Pre-accelerator \\
Structure 1 (E1) & 2013 & 1 & Technological Innovation Center \\
\hline
\end{tabular}

Source: elaborated by the authors.

P1 - Innovation Center - is located in one of the university's campuses, which concentrates several undergraduate and graduate courses in Informatics and related areas. Its institutional mission is to support the development of the local ecosystem (Document 01), but this mission is translated by its coordinator as "being a tugboat" for the university (Interviewee 1), debating topics "that are not yet happening or are not debated in Brazil". This fact is facilitated by the proximity that Program 1 has with its maintaining organization - Microsoft - and partner of the university, which is located in Silicon Valley. The Innovation Center has a dynamic structure and operations. Programs that previously worked in introducing students to the job market, now try to bring relevant companies from the local ecosystem to the university, and help them - with groups formed by the students - in processes of intervention to establish technological innovations.

In the case of P2 - Pre-incubator - located on the university's main campus, the Program was established in 2014. Seeking a program that would differ from the others, the coordinating professor inaugurated a sustainable business incubator, which proposed to generate social and environmental impact. With an interactive and flexible work process, Program 2 works by receiving students from the university who have innovative and sustainable ideas, in addition to intervening in organizations that operate outside the university walls. Currently, the Pre-incubator no longer uses edicts for project evaluation, but "a routine of keeping the doors open for students" (Interviewee 2).

In turn, the P3 - Pre-accelerator - was created from the perception of opportunity of its current coordinator, who also teaches courses of entrepreneurship. As part of a group aimed at promoting technological entrepreneurship, it ended up institutionalizing a Pre-accelerator. The Program acts in an itinerant way through the institution's campuses, with the purpose of helping entrepreneurs in the initial stage of the entrepreneurial process, making them more qualified for external processes. Examples include Meetups, Roadshows and Assessment Boards that discuss the development of business models and the aforementioned MVP's - Minimum Viable Products.
Unlike the programs listed above, the $\mathrm{E} 1$ Technological Innovation Center (NIT) - was consolidated in 2013 (Document 02). Due to the recent institutionalization and lean team, the agency acts with less emphasis and scope when compared to previous programs. Initially, the NIT was concerned with the dissemination of the culture of innovation at the university, stimulating the care with the protection of knowledge. In the words of the Coordinator, "a more passive than active daily life" (Interviewee 4). At the end of 2018, the NIT established a new innovation hub for the university that began its activities in the first half of 2019 (Document 06).

Actions to promote entrepreneurship and innovation in private universities are carried out in a decentralized manner, with actions being reported on several campuses and joint actions between the programs, with direct action of the coordinators and support from NIT.

The programs also complement each other. The most emblematic case arises from the interaction between P2 Pre-incubator - and P3 - Pre-accelerator - since both deal with issues related to the beginning of the entrepreneurial process. While P2 works more closely with the Institute of Economic and Management Sciences, P3 works with the Institute of Exact Sciences and Informatics, with a more technological bias. The NIT's action seeks, then, to avoid overlaps and to allow positive results of the projects, following them and guarding them institutionally. However, the fear of cannibalization of the projects is real and highlighted by the coordinators. Despite the perception of improvement in the relations between the university and the market, both highlight that there is still much work to be done.

On the other side of the research analysis spectrum are the technology-based enterprises of students and alumni of the private university. Table 6 presents the initial information of the researched ventures. It should be noted that the ventures are characterized by diversity not only in their business models, but also in the stage they are at in their entrepreneurial journey.

\section{Table 6}

Initial information of the ventures researched at the private university

\begin{tabular}{llllll}
\hline Name & Foundation & Staff & Billing (2017) & Partner program & $\begin{array}{l}\text { External } \\
\text { Financing }\end{array}$ \\
\hline Alpha Company & 2016 & 2 & $\mathrm{R} \$ 1,000.00$ & $\mathrm{P} 2$ & No \\
Beta Company & 2016 & 5 & $\mathrm{R} \$ 0.00$ & $\mathrm{P} 1$ & No \\
Gama Company & 2012 & 60 & $\mathrm{R} \$ 3$ million & - & No \\
\hline
\end{tabular}

Source: elaborated by the authors. 
Alfa Company identifies itself institutionally as a facilitator of the academic life of dental students, valuing sustainability in the reuse of materials and non-disposable instruments used by students. Focusing on the retail market and also on intermediating transactions among consumers, the organization integrates individuals and companies that wish to sell new and used dental equipment and accessories.

The Beta Company, in turn, developed and sells an application that aims to facilitate the experience of the deaf in traffic, through artificial intelligence, generating greater security and comfort to users by identifying external sounds and replicating them on the user's phone.

Gama operates in the digital innovation market, helping other organizations to face the technological revolution in markets already developed, such as banking and mineral extraction. The company offers solutions through digital transformation for the production of business models that integrate the digital operations of organizations or strategies that use digital tools, such as mobile applications.

Analyzing the researched entrepreneurs at the private university, the university had influence on both the constitution of the researched enterprises and the formation of the work teams - directly in the companies Alfa and Beta, and indirectly in the case of Gama Company. In the case of the first two, the business ideas went through the scrutiny of the university programs, P1 - Innovation Center - and P2 Pre-incubator. In the case of Gama Company, although the link with a private incubator that actively participates in the local ecosystem, Entrepreneur C highlights that it maintained an active position when it was graduating, charging teachers and institutional actors to create links with the market. The curriculum for these entrepreneurs was relevant for the acquisition of entrepreneurial and managerial knowledge. "Management disciplines" were significant for the entrepreneurs to be introduced to the subject, instigating them to go deeper into it. There was consensus among those interviewed that the University is experiencing a positive moment, with closer ties with different organizations.

Although there is an active moment of the University, however, the performance of the university programs can be considered embryonic, in the sense of having only an internal impact, still incapable of stimulating the enterprises that participated in the programs to great leaps in the local ecosystem. In the case of Alfa Company, after the preincubation process had been abandoned, problems in the operation were noted, which led the entrepreneur and his team to interrupt the formal operations, currently operating in an informal manner. In the case of the Beta Company, it is still in its initial format, since the product has recently undergone transformations and has not yet been brought to market scrutiny. The case of Gama Company is symbolic, since it is the company with the greatest impact among the three and had a link with an external actor to the university, already active in the ecosystem, which ended up helping the growth of the business.

Entrepreneurs, in general, also emphasize the importance of the managerial knowledge learned at the university, as well as the experiences obtained in the labor market. They believe that the experience in the labor market has facilitated the establishment of the enterprise, uniting the academic knowledge in management with the technical knowledge obtained from business experiences and amplified through mentoring - carried out by the university and also by actors outside the institution. In the case of the latter - mentoring - the positive perception of the process in the evaluation of entrepreneurs should be highlighted. Offered to Alfa and Beta Companies by the University and, by private agents, to the three companies, the mentoring generated new insights to entrepreneurs and new perspectives for business application.

Finally, the lack of stronger links between the enterprises and the university is also highlighted. The Alfa Company, for example, has no formal link with the institution, using only the informal network for its operation. Similarly, the Beta Company, despite still having an informal link with P1 - Innovation Center -, does not project this link for its future, fixing itself only on the possibility of patent registration together with the university. Finally, in the case of Gama Company, the link is restricted to hiring students from the university, when necessary, and participating in one-off lectures.

\section{Table 7}

Summary of factors that influence the creation of TBF at the Private University

\begin{tabular}{ll}
\hline Categories & Evidence \\
\hline $\begin{array}{l}\text { Technical } \\
\text { Support }\end{array}$ & $\begin{array}{l}\text { Courses on entrepreneurship (in the } \\
\text { curricular grid) }\end{array}$ \\
$\begin{array}{l}\text { Specialized } \\
\text { Eupport }\end{array}$ & $\begin{array}{l}\text { Events, lectures, competitions and } \\
\text { mentoring }\end{array}$ \\
$\begin{array}{l}\text { Physical } \\
\text { Structure }\end{array}$ & $\begin{array}{l}\text { Innovation center, pre-incubator, pre- } \\
\text { accelerator, extension, study rooms, } \\
\text { laboratories }\end{array}$ \\
$\begin{array}{l}\text { Entrepreneurial } \\
\text { and } \\
\text { management } \\
\text { skills }\end{array}$ & $\begin{array}{l}\text { Entrepreneurial and management skills, } \\
\text { such as knowledge in marketing, finance } \\
\text { and people management are mostly } \\
\text { acquired in experiences of immersion in } \\
\text { the labor market. Experiences, in general, } \\
\text { provided by the university }\end{array}$ \\
& $\begin{array}{l}\text { Enterprises are generated and } \\
\text { emancipated from university programs, but } \\
\text { they go through difficulties and the } \\
\text { subsequent link with the entity weakens }\end{array}$ \\
Creating a new \\
business
\end{tabular}

Source: elaborated by the authors.

\subsection{Case 2 - Public University}

\subsubsection{Description of the case 2}

Founded on September 7, 1927, the institution included in this research as a public university is considered one of the best universities in the country. The university is home to approximately 49,000 students, 3,000 professors - 
among them, $734 \mathrm{CNPq}$ researchers - in 4 university campuses in several cities of Minas Gerais (Document 19).

The institution ranks 4th overall among the best universities in the country and reaches an index of 39.95 in research and 3.55 in innovation, which places it in 7th and 4th overall, respectively, among the national institutions in the University Ranking Folha de ano de 2018. The innovation indicator, which takes into account the number of patent registrations and possibilities of technology transfer to society, led the university to the leadership in the national patent filing ranking in 2016 (Document 07). Only in international patent deposits, there were 20 in the year 2017 , and added to the previous ones, generated $R \$$ $650,000.00$ in economic gains to the entity (Document 11).

First of all, it is important to highlight the maturity of the programs and structures to foster entrepreneurship and innovation of this public university. The university's NIT stands out in this panorama. Table 8 below lists the program and structures researched at the public university.

Table 8

Programs and structures to support and promote entrepreneurship mapped at the public university

\begin{tabular}{llll}
\hline Programs & Beginning of activities & $\begin{array}{l}\text { Number of teachers working } \\
\text { directly }\end{array}$ & Classification \\
\hline Program 4 (P4) & 2014 & 2 & Pre-accelerator (currently) \\
Structure 2 & 1997 & - & Technological Innovation Center \\
Structure 3 & 2012 & 1 & Technology Park \\
\hline
\end{tabular}

Source: elaborated by the authors.

In the case of Program 4 - Pre-accelerator - its creation is linked to an announcement from the INCT National Institute of Science and Technology 2014. With the mission of "transforming academic research into wealth and sustainable development for Brazil, through entrepreneurial initiatives" (Document 14), something was planned that would generate impact, encompassing technology transfer to the market. The Program operates on three axes: (i) technological, focused on research; (ii) entrepreneurship, licensing of technologies in the market and creation of new companies and (iii) education, which involves entrepreneurial training and exchange with high school students. The idea is that the Program evolves and starts to embrace new technologies generated at the university and interact with other partners of the local ecosystem.

The NIT, created in 1997, acts in the "protection of intellectual property assets generated in the university, partnerships and licensing of technologies and incubation and entrepreneurship actions" (Document 12). The work of the Coordination - from the patent research process to the final transfer - is carried out by a multidisciplinary team, without division into defined sectors, but considered effective for acquiring information, research results and technologies developed by the university. Considering the 22 years of NIT's foundation (1997 - 2019), programs to support innovation and entrepreneurship have become frequent. The actions supported by the Coordination have "a very focused formative entrepreneurship", and end up becoming "a storehouse of talent" (Interviewee 9). Training of entrepreneurs and development courses in management tools are also carried out.

In 2012, the university's development activities reached a new milestone, with the inauguration of a Technology Park, a partnership between the university, private initiative and the state government of Minas Gerais. The Park aims to strengthen ties between university and business, generate innovation, create investment opportunities in new technology-based firms, and revitalize the productive base of the economy through the incorporation of knowledge. The Park's team is composed of eight people, with revenues of approximately $R \$ 265$ million in 2017 (Document 08) and the generation of $R \$ 3$ million in taxes in the same year.

For the representatives of the pre-accelerator, the NIT and the Technological Park, the interaction movement between the university and the companies is in a positive moment, where recent changes in federal legislation and the institution itself have facilitated coexistence. However, it should be emphasized that this relationship is still considered to be less than desirable. Despite the cooling down of conflicts between internal groups of the university pro and against the greater integration with the market, the need for real cases of entrepreneurial success in the ecosystem was highlighted, so that one can reinforce the efforts of the university, besides the greater dissemination of entrepreneurial culture in its internal environment. According to the interviewees, the recognition of the achievements of the university would chancel the efforts to promote entrepreneurship and innovation, proving that the relationship between university and market can, in fact, contribute to the economic development of the region.

The situation is illustrated, according to the interviewees, by the programs to promote entrepreneurship that have multiplied in recent years. Despite the large number of programs in different departments, there are barriers - physical and cultural - since there is little interaction between researchers, institutes and laboratories. This factor is accentuated by the recognized independence of professors and their research, which ends up contributing to the lack of partnerships and documentation of lessons learned. However, the receptivity of the students to entrepreneurial initiatives is positive, since they are motivated to participate in the available events and programs, which are characterized by being distinct from classroom dynamics. 
Two technology-based ventures of two former university students make up the complementary part of university analysis. Table 9 presents the initial information of entrepreneurs and researched ventures. It is noted that the ventures are characterized by the diversity of their business models, but they are similar in the lack of relationship with university programs.

\section{Table 9}

Initial information of entrepreneurs and researched ventures

\begin{tabular}{llllll}
\hline Name & Foun-dation & Staff & Billing (2017) & Partner program & $\begin{array}{l}\text { External } \\
\text { Financing }\end{array}$ \\
\hline Delta Company & 2013 & $>150$ & Over $R \$ 60$ million & - & No \\
Sigma Company & 2013 & 9 & $\begin{array}{l}\text { Approximately } \\
\mathrm{R} \$ 30,000.00\end{array}$ & - & Yes \\
\hline
\end{tabular}

Source: elaborated by the authors.

Delta Company defines itself institutionally as a way to provide more frequent travel to its customers, "creating possibilities" from the reduction of airfare costs through the transaction in air miles. The operation is established from users who wish to buy tickets at a lower price - at a discounts - without the need for miles, since other users - who have excess miles - market them on the same platform, making profitable points that would eventually expire.

The Sigma Company, in turn, offers "the opportunity to take better care of yourself and carry in your pocket" (Interviewee 12), personal information about the health of the user, directed to pregnant women in the prenatal exam phase. Exploring the offer of "reliable clinical information", it connects health professionals, patients and maternity hospitals through the application that acts as a key product of the organization. In addition, the application has a "support network", so that pregnant users can relate to each other, in an exchange of experiences and doubts proper to the gestational process.

According to the entrepreneurs researched, the university had little influence both in the idealization of the business and in the constitution of the work teams. While the ideas emerged at moments considered "at random", after great immersion and experience in the labor market, the teams - which exhibit multidisciplinary traits - were formed over time and with diverse influences. Entrepreneurs were emphatic in emphasizing that the university did not offer them entrepreneurial and managerial tools. Such support was obtained through external partners.

The lack of managerial knowledge is seen as one of the factors that prevented Delta Company from growing beyond the current results. Entrepreneur $\mathrm{D}$ believes that the problems faced by the company in its first moments would have been smaller, or solved more quickly, if it had had more managerial knowledge. In the case of Sigma Company, this fact is repeated, since the first managerial knowledge was obtained with private actors and during experience in the labor market. However, Entrepreneur E emphasizes the importance of the technical knowledge provided by the university to make the experience in the labor market possible. The need for knowledge in entrepreneurship and management at the beginning of the entrepreneurial process was remedied through cycles of acceleration, private in the case of Entrepreneur D, and, ironically, by an accelerator that has partnership with the public university in the case of Entrepreneur E. At this time, the performance of mentors was also very highlighted, especially in generating insights and deepening management techniques.

It is important to emphasize that entrepreneurs agree on the contribution of the university in their human formation. While Entrepreneur $D$ points out that the labor market was more important than the university to undertake, "as a human being, probably not" (Interviewee 11); fact also highlighted by Entrepreneur E, given that the competitive differential of his undertaking before the competitors would be "in the view of the health problem" that the company defends (Interviewee 12).

Finally, the lack of a more permanent link between the enterprises and the university is also highlighted. In the case of Delta Company, Entrepreneur D has a history of participating in lectures given by the university and also of participating in an acceleration program with ties to the university, but points out that there is no formalized partnership. The Sigma Company, on the other hand, points out that it was sought to initiate cooperation with the university, but the contacts did not have continuity.

\section{Table 10}

Summary of factors that influence the creation of TBF at the Public University

\begin{tabular}{|c|c|}
\hline Categories & Evidence \\
\hline Technical Support & $\begin{array}{l}\text { Courses about entrepreneurship (in the } \\
\text { curricular grid; courses and trainings } \\
\text { about entrepreneurship) }\end{array}$ \\
\hline $\begin{array}{l}\text { Specialized } \\
\text { Support }\end{array}$ & $\begin{array}{l}\text { Events; lectures; competitions; and } \\
\text { mentoring }\end{array}$ \\
\hline Physical Structure & $\begin{array}{l}\text { Incubator; pre-accelerator; study rooms; } \\
\text { extension; laboratories; technology park }\end{array}$ \\
\hline $\begin{array}{l}\text { Entrepreneurial } \\
\text { and management } \\
\text { skills }\end{array}$ & $\begin{array}{l}\text { Entrepreneurial and management skills, } \\
\text { such as hiring knowledge, finance and } \\
\text { legal skills learned through external } \\
\text { mentoring and entrepreneurial processes } \\
\text { - acceleration. Professional experiences, } \\
\text { acquired through the university, expand } \\
\text { skills }\end{array}$ \\
\hline $\begin{array}{l}\text { Creating a new } \\
\text { business }\end{array}$ & $\begin{array}{l}\text { Enterprises are generated outside the } \\
\text { university's entrepreneurship programs. } \\
\text { Indirect influences from the university } \\
\text { would lead to the entrepreneurial journey } \\
\text { that started "at random". }\end{array}$ \\
\hline
\end{tabular}

Source: elaborated by the authors. 


\subsection{Cross analysis of cases}

After the description and individual analysis of the cases, we carry out the comparison of the cases. Taking the category Physical Structure as a reference, it was found that there are quantitative and qualitative differences in favor of the public university - incubator, pre-accelerator, study rooms, extension, laboratories and technology park - in comparison with the private university - innovation center, pre-incubator, pre-accelerator, extension, study rooms and laboratories. The structure provided by the public university, positions it ahead when considering the volume of activities that identify it as an entrepreneurial university, such as the number of patents and licensing, spin-off generation and the existence of technology park (Phillpott et al., 2011), characteristic of hybridization and technology transfer activities (Etzkowitz, 2004; Tornatzky \& Rideout, 2014).

In the case of the private university, activities of an entrepreneurial nature would be restricted to research agreements, given that the processes for obtaining patents and licenses are incipient, perhaps justified by the relatively recent performance of the NIT. Actions directed at obtaining patents and licensing innovations developed at universities enable income diversification (Clark, 2001) or capitalization (Etzkowitz, 2004) and is more widely used by the public university, and still little used by the private counterpart. However, both universities have been found to lack strong administrative capacity (Clark, 2001; 2006) or leadership (Tornatzky \& Rideout, 2014), as the programs operate independently and without integration in both private and public universities. In the public university, entrepreneurship support programs are designed and offered by independent professors and only in a few departments with a greater link to applied research (Phillpott et al., 2011), but with no connection to other laboratories and researchers, acting outside NIT operations. In this sense, it is noticeable that the actions of formation and stimulus to entrepreneurship in the universities researched are derived much more from initiatives of professors involved with the subject, not being substantiated yet, and very evidently, in practices planned by higher administration.

Considering the category Technical Support, courses of entrepreneurship in curriculum and training on entrepreneurship (Gnyawali \& Fogel, 1994; Foster \& Shimizu, 2013) are offered by both institutions. In the case of the former, with greater emphasis on the private university, and the latter more present at the public university - which time or again present themselves as events or competitions. However, although offered, the entrepreneurial disciplines of the undergraduate degree were perceived as little contributory in the view of entrepreneurs linked to the private university, but although they recognize that the introduction to the subject has encouraged them to go deeper into the subject. In the case of the public university, the curricular disciplines were not identified by the researched entrepreneurs, and the extracurricular disciplines on entrepreneurship would have in its nature the predilection only by "really interested" students, being taught in a different way to the subjects taught in class. Both traditional curricular subjects and the offer of extracurricular courses are part of the education trends in entrepreneurial universities (Tornatzky \& Rideout, 2014), however, the coordinators have not verbalized which type they consider more appropriate, and believe that both can be used, but at different times (Interviewee 02; Interviewee 14).

The scarcity of technical support at universities has been relatively filled by the provision of Specialized Support, mostly provided by external private organizations. The mentoring offered by actors with entrepreneurial experience allowed for moments of intense learning. In general, the evaluation of entrepreneurs was that they had little or no knowledge in management when they created their companies, being the knowledge obtained through professional experience and mentoring processes.

The lack of depth in technical support generated weaknesses in entrepreneurial skills and management compromising the entry into the entrepreneurial process, according to respondents. The knowledge obtained in class or extracurricular were not enough to prevent obstacles before the beginning of the entrepreneurial journey - such as planning execution - nor during the operation, once management problems involving people management, financial management and legal processes were reported. The skills were mostly acquired during experiences in the labor market, being later amplified by mentoring processes. The researched entrepreneurs recognize, however, that the experiences in the labor market were possible due to the technical knowledge and qualification obtained in the respective university courses.

Finally, the creation of new business occurs, but still in a turbulent way. In the case of the private university, emancipated businesses go through difficulties - Alfa Company -, or there is little perspective of the relationship in the future - Beta Company. But the factor that stands out is the creation of enterprises outside the university programs - Gama Company, Delta and Sigma. In these cases, university relations and structures - technical support, physical structure and specialized support - were almost entirely provided by external private actors, which shows a weak link with the respective universities of origin of the entrepreneurs.

Figure 3 summarizes the results found on the contribution of universities to the student entrepreneurship process, which we discuss below. 


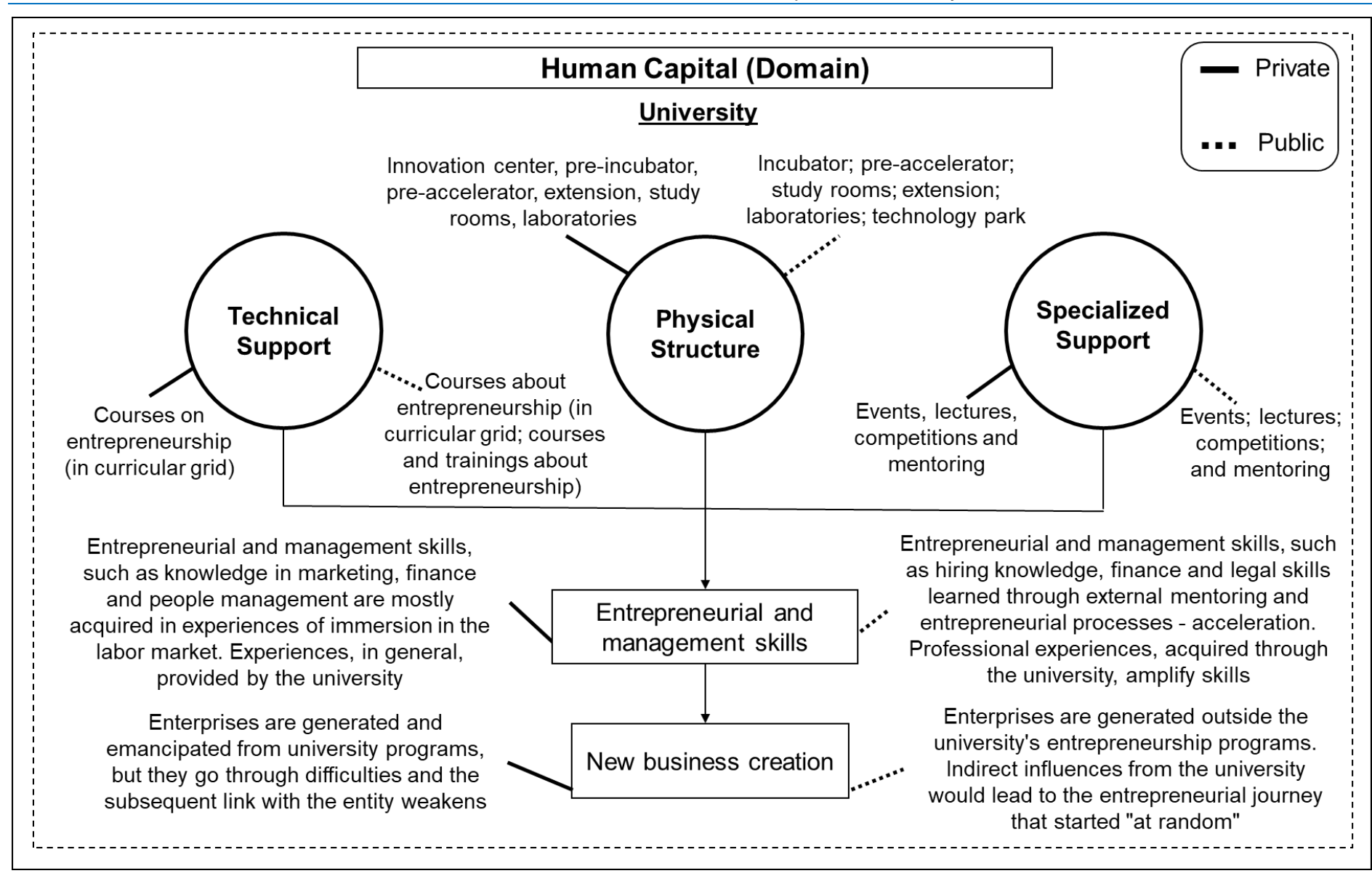

Figure 3. Summary of research findings.

Source: elaborated by the authors.

\section{CONCLUSIONS}

Although it has been trend in the current literature (Brown \& Mason, 2017), the theme of entrepreneurial ecosystems still lacks further research (Acs et al., 2017), especially regarding the relationships and influences between the domains (Borissenko and Boschma, 2015) and ecosystems that demonstrate some dysfunction or failure, different from the more documented success cases (Mack \& Mayer, 2015).

Taking the theoretical model elaborated as a reference of this research, it was possible to identify that the universities researched - one of private character and another of public nature - have a robust structure. However, even with the existence of several programs and researches directed to the promotion of entrepreneurship and innovation, there is little or no integration between them. This fact denotes the absence of effective central coordination in the institutions, raises the fear of cannibalization of activities and the possibility of rework, since there is a lack of record of lessons learned.

The greater number of programs to promote and support entrepreneurship allows the relationship between the university and companies to be expanded. However, in the cases studied, the programs are still restricted to specific departments, generally with a greater link to applied sciences. It was found, for example, that entrepreneurs did not make extensive use of entrepreneurial support programs and structures for the creation of their enterprises. Armed with the technical knowledge acquired in the graduation course, the entrepreneurs developed entrepreneurial skills through experiences in the labor market, which later were amplified in mentoring - considered by entrepreneurs as of fundamental importance for the business. It is worth mentioning that the entrepreneurs and the organizations studied that had the greatest impact on the regional ecosystem ended up seeking knowledge and management skills in partnerships with private actors outside the university. The strengthening of ties with these private actors resulted in a reduction of the relationship between entrepreneurs and universities.

The analysis of the influence of university institutions on the entrepreneurial process of egresses allowed us to suggest that the $\mathrm{HEl}$, as a way of contributing to the strengthening of entrepreneurial and management skills, invest in the offer of practical and managerial courses, of short duration, to the egresses who have assumed an entrepreneurial career. The offer of courses of this nature can help to strengthen ties with entrepreneurs, making them mentors and speakers in new events and programs developed by the university. In addition, it is worth highlighting the possibility of greater dissemination, by universities, to the internal and external public, of their efforts and results in entrepreneurship and innovation activities. The exhibition of the results - whose absence was felt mainly in the case of the private university - could act 
both as an integrator of the programs and structures that have no connection, and in clarifying to the general public about the prominent role that such institutions have in the ecosystem. It is even believed that improving the communication strategy could improve the perception of the entrepreneurs towards the number of projects and structures that universities offer.

As a suggestion for future research, it is recommended that the research include other aspects of the ecosystem, as factors influencing the formation of technology-based firms, increasing understanding about the interaction of universities and other ecosystem actors. Furthermore, consider the insertion of entrepreneurial universities in national regional contexts (Thomas \& Pugh, 2020), reinforcing Brazilian regional differences and the formulation - and impacts - of innovations in society (Carayannis \& Rakhmatullin, 2014). For future work, it is also recommended to increase the number of TBF studied, which will enable a better understanding about the participation of the university in the formation of technologybased firms.

\section{REFERENCES}

Acs, Z. J., Stam, E., Audretsch, D. B., \& O'Connor, A. (2017). The lineages of the entrepreneurial ecosystem approach. Small Business Economics, 49(1), 1-10. https://doi.org/10.1007/s11187-017-9864-8

Arruda, C., Cozzi, A., Nogueira, V., \& Costa, V. (2013). O ecossistema empreendedor brasileiro de startups: uma análise dos determinantes do empreendedorismo no Brasil a partir dos pilares da OCDE. In Núcleo de Inovação e Empreendedorismo (pp. 1-51). FDC - Fundação Dom Cabral.

https://www.fdc.org.br/conhecimento/publicacoes/relatoriode-pesquisa-28442

Audretsch, D. B., \& Belitski, M. (2017). Entrepreneurial ecosystems in cities: establishing the framework conditions. The Journal of Technology Transfer, 42, 10301051. https://doi.org/10.1007/s10961-016-9473-8

Bardin, L. (2011). Organização da análise. In L. Bardin. Análise de conteúdo (pp. 125-170). Edições 70.

Borissenko, J., \& Boschma, R. (2017). A critical review of entrepreneurial ecosystems research: towards a future research agenda. CIRCLE Working Paper, 1-25. https://ideas.repec.org/p/hhs/lucirc/2017 003.html

Brown, R., \& Mason, C. (2017). Looking inside the spiky bits: a critical review and conceptualization of entrepreneurial ecosystems. Small Business Economics, 49(1), 11-30. https://doi.org/10.1007/s11187-017-9865-7

Cao, Z., \& Shi, X. (2020). A systematic literature review of entrepreneurial ecosystems in advanced and emerging economies. Small Business Economics, 57, 75-110. https://doi.org/10.1007/s11187-020-00326-y

Carayannis, E. G., \& Rakhmatullin, R. (2014). The quadruple/quintuple innovation helixes and smart specialisation strategies for sustainable and inclusive growth in Europe and beyond. Journal of Knowledge Economy, 5(2), 212-239. https://doi.org/10.1007/s13132$\underline{014-0185-8}$

Clark, B. R. (2001). The entrepreneurial university: new foundations for collegiality, autonomy, and achievement. Journal of the Programme on Institutional Management in

Higher Education, 13(2),

9-25.

http://www.oecd.org/edu/imhe/37446098.pdf

Clark, B. R. (2006). Pursuing the entrepreneurial university. In J. Audy \& M. Morosini (Orgs.), Innovation and entrepreneurialism in the university (pp. 15-27). EDIPCURS.

http://nit.uesc.br/portal/assets/files/livros/Inovacao e Emp reendedorismo na Universidade.pdf

Dahlstrand, A. L. (2007). Technology-based entrepreneurship and regional development: the case of Sweden. European Business Review, 19(5), 373-384. https://doi.org/10.1108/09555340710818969

Einsenhardt, K., \& Graebner, M. (2007). Theory building from cases: opportunities and challenges. Academy of Management Journal, 50(1), 25-32. https://doi.org/10.5465/amj.2007.24160888

Eisenhardt, K. M. (1989). Building theories from case study research. The Academy of Management Review, 14(4), 532-550. https://doi.org/10.2307/258557

Etzkowitz, H. (2004). The evolution of the entrepreneurial university. International Journal of Technology and Globalization, 1(1), https://doi.org/10.1504/IJTG.2004.004551

Etzkowitz, H. (2016). The entrepreneurial university: Vision and metrics. Industry \& Higher Education, 30(2), 83-97. https://doi.org/10.5367/ihe.2016.0303

Etzkowitz, H., \& Leydesdorff, L. (2000). The dynamics of innovation: from National Systems and "Mode 2" to a Triple Helix of university-industry-government relations. Research Policy, 29, 109-123. https://doi.org/10.1016/S00487333(99)00055-4

Etzkowitz, H., \& Zhou, C. (2017). Hélice tríplice: Inovação e empreendedorismo universidade - indústria - governo. Estudos Avançados, 31(90), 23-48. https://doi.org/10.1590/s0103-40142017.3190003

Etzkowitz, H., Webster, A., Gebhardt, C., \& Terra, B. R. C. T. (2000). The future of the university and the university of the future: evolution of ivory tower to entrepreneurial paradigm. Research Policy, 29, 313-330. https://doi.org/10.1016/S0048-7333(99)00069-4

Foster, G., \& Shimizu, C. (2013). Entrepreneurial ecosystems around the globe and company growth dynamics. In Annual Meeting of the New Champions 2013 (pp. 1-36). http://www3. weforum.org/docs/WEF EntrepreneurialEcos ystems Report 2013.pdf

Fritsch, M., \& Wyrwich, M. (2018). Regional knowledge, entrepreneurial culture, and innovative start-ups over time and space - an empirical investigation. Small Business Economics, 51(2), 337-353. https://doi.org/10.1007/s11187-018-0016-6

Fusch, P. I., \& Ness, L. R. (2015). Are we there yet? Data saturation in qualitative research. The Qualitative Report, 20(9). 1408-1416. $\quad$ https://doi.org/10.46743/21603715/2015.2281

Ganotakis, P. (2012). Founders' human capital and the performance of UK new technology based firms. Small Business Economics, 39, 495-515. https://doi.org/10.1007/s11187-010-9309-0

Gaskel, G. (2003). Entrevistas individuais e grupais. In G. Gaskell \& M. Bauer (Orgs.), Pesquisa qualitativa com texto, imagem e som: Um manual prático (pp. 64-89). Vozes.

Global Entrepreneurship Index. (2017). The Global Entrepreneurship Index 2017. https://thegedi.org/2017global-entrepreneurship-index/

Global Entrepreneurship Monitor. (2019). 2019/2020 Global Report. https://www.gemconsortium.org/report/gem-20192020-global-report 
Silva, Guimarães, Inácio \& Castro - Entrepreneurial ecosystem

Gnyawali, D. R., \& Fogel, D. S. (1994) Environments for entrepreneurship development: key dimensions and research implications. Entrepreneurship Theory and Practice, 18(4), 43-62. https://doi.org/10.1177/104225879401800403

Guerrero, M., \& Urbano, D. (2017). The impact of Triple Helix agents on entrepreneurial innovations' performance: An inside look at enterprises located in na emerging economy. Technological Forecasting \& Social Change, 119, 294-309. https://doi.org/10.1016/.techfore.2016.06.015

Inácio, E., Jr., Autio, E., Morini, C., Gimenez, F., A., P., \& Dionisio, E., A. (2016). Analysis of the brazilian entrepreneurial ecosystem. Desenvolvimento em Questão, 14(37), 5-36. https://doi.org/10.21527/2237-6453.2016.37.5-36

Isenberg, D. (2011). The entrepreneurship ecosystem strategy as a new paradigm for economy policy: Principles for cultivating entrepreneurship. The Babsom Entrepreneurship Ecosystem Project. http://www.innovationamerica.us/images/stories/2011/Theentrepreneurship-ecosystem-strategy-for-economicgrowth-policy-20110620183915.pdf

Leydesdorff, L. (2000). The triple helix: An evolutionary model of innovations. Research Policy, 29, 243-255. https://doi.org/10.1016/S0048-7333(99)00063-3

Mack, E., \& Mayer, H. (2015). The evolutionary dynamics of entrepreneurial ecosystems. Urban Studies, 53(10), 21182133. https://doi.org/10.1177\%2F0042098015586547

Marshall, A. (1985). Princípios de Economia. Nova Cultural.

Maskell, P., \& Kebir, L. (2009). What qualifies as a cluster theory? DRUID Working Paper, 1-21. https://ideas.repec.org/p/aal/abbswp/05-09.html

Mason, C., \& Brown, R. (2014). Entrepreneurial ecosystems and growth oriented entrepreneurship. In LEED Programme and the Dutch Ministry of Economic Affairs (pp. 1-30). http://www.oecd.org/cfe/leed/entrepreneurialecosystems.pdf

Mineiro, A. A. C., Souza, D, L., Vieira, K. C., Castro, C. C., \& Brito, M. J. (2018). Da hélice tríplice a quíntupla: uma revisão sistemática. E\&G - Economia \& Gestão, 18(51), 77-93. https://doi.org/10.5752/P.1984-6606.2018v18n51p77-93

National Association of Innovative Enterprise Promoting Entities ANPROTEC. (2019). Mapeamento dos Mecanismos de Geração de Empreendimentos Inovadores no Brasil. https://anprotec.org.br/site/wp-

content/uploads/2019/09/Mapeamento Empreendimentos Inovadores.pdf

Neumeyer, X., Santos, S. C., \& Morris, M. H. (2019). Who is left out: exploring social boundaries in entrepreneurial ecosystems. The Journal of Technology Transfer, 44, 462484. https://doi.org/10.1007/s10961-018-9694-0

Phillpott, K., Dooley, L., O'Reilly, C., \& Lupton, G. (2011). The entrepreneurial university: Examining the underlying academic tensions. Technovation, 31, 161-170. https://doi.org/10.1016/j.technovation.2010.12.003

Plonski, G. A. (1999). Cooperação universidade-empresa: um desafio gerencial complexo. Revista de Administração da $\begin{array}{llll}\text { USP } & \text { - RAUSP, } & \text { 34(4), }\end{array}$ http://200.232.30.99/download.asp?file=3404005.pdf

Ragin, C. (1992). Introduction: Cases of "what is a case?". In C. Ragin \& H. Becker (Eds.), What is a case? (pp. 1-17). Cambridge University Press.

Ribeiro, A. T. V. B., Uechi, J. N., \& Plonski, G. A. (2018). Building builders: entrepreneurship education from an ecosystem perspective at MIT. Triple Helix, 5(3), 1-20. https://doi.org/10.1186/s40604-018-0051-y

Ruiz, S. M. A., \& Martens, C. D. P. (2019). Universidade empreendedora: proposição de modelo teórico.
Desenvolvimento em Questão, 17(48), 121-138.

https://doi.org/10.21527/2237-6453.2019.48.121-138

Schubert, T., \& Kroll, H. (2016). Universities' effects on regional GDP and unemployment: the case of Germany. Papers in Regional Science, 95(3), 467-490. https://doi.org/10.1111/pirs.12150

Serviço Brasileiro de Apoio às Micro e Pequenas Empresas. (2016). Empreendedorismo nas universidades brasileiras. https://m.sebrae.com.br/Sebrae/Portal\%20Sebrae/Anexos /Relatorio\%20Endeavor\%20impressao.pdf

Spigel, B. (2015). The relational organization of entrepreneurial ecosystems. Entrepreneurship Theory and Practice, 41(1), 49-72. https://doi.org/10.1111/etap.12167

Suddaby, R., Bruton, G. D., \& Si, X. S. (2015). Entrepreneurship through a qualitative lens: insights on the construction and/or discovery of entrepreneurial opportunity. Journal of Business $\quad$ Venturing, $30(1), \quad 1-10$. https://doi.org/10.1016/j.jbusvent.2014.09.003

Thomas, E., \& Pugh, E. (2020). From 'entrepreneurial' to 'engaged' universities: Social innovation for regional development in the Global South. Regional Studies, 54(12), 1-14. https://doi.org/10.1080/00343404.2020.1749586

Tornatzky, L. G., \& Rideout, E. C. (2014). Innovation U 2.0: reinventing university roles in a knowledge economy. http://www.innovation-u.com/InnovU-2.0 rev-12-14-14.pdf

Torres, S., Alves, S., \& Vidal, F. (2017). Parques tecnológicos como empreendimentos imobiliários na América Latina. Contextus - Revista Contemporânea de Economia e Gestão, 15(1), 84-121. https://doi.org/10.19094/contextus.v15i1.883

Volles, B. K., Gomes, G., \& Parisotto, I. R. S. (2017). Universidade empreendedora e transferência de conhecimento e tecnologia. $\quad R E A d, \quad 86(1), \quad 137-155$. https://doi.org/10.1590/1413-2311.03716.61355

Yin, R. K. (2010). Projetando estudos de caso. In R. K. Yin (Ed.), Estudo de caso: Planejamento e método (pp. 39-79). Bookman.

\section{ACKNOWLEDGMENT}

The authors would like to thank the Research Support Foundation of the State of Minas Gerais (FAPEMIG) for the financial support for the research of this article. 


\section{CONTEXTUS}

\section{REVISTA CONTEMPORÂNEA DE ECONOMIA E GESTÃO}

\section{CONTEXTUS}

CONTEMPORARY JOURNAL OF ECONOMICS AND

MANAGEMENT.

\section{ISSN 1678-2089}

ISSNe 2178-9258

1. Economics, Administration and Accounting - Journal

2. Federal University of Ceara. Faculty of Economics,

Administration, Actuaries and Accounting

\section{FACULTY OF ECONOMICS, ADMINISTRATION, ACTUARIES} AND ACCOUNTING

University Av. - 2486, Benfica

60020-180, Fortaleza-CE

BOARD: Paulo Rogério Faustino Matos Danielle Augusto Peres

Website: www.periodicos.ufc.br/contextus

E-mail: revistacontextus@ufc.br

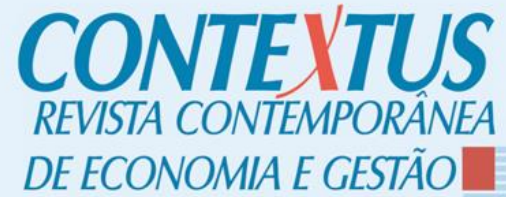

UNIVERSIDADE

FEDERAL

DO CEARÁ

FACULDADE

DE ECONOMIA,

ADMINISTRAÇÃO,

ATUÁRIA

E CONTABILIDADE

\section{Qlualis}

Contextus is classified in the Qualis - Capes system as a B1 journal, in the area of Public and Business Administration, Accounting and Tourism (2013-2016).

DORA

Contextus agrees and signs the San Francisco Declaration on Research Assessment (DORA).

$\triangle \mathrm{BEC}$. Contextus is associated with the Brazilian B R A S I L Association of Scientific Editors.

This work is licensed under a Creative Commons Attribution - NonCommercial 4.0 International license.
EDITOR-IN-CHIEF

Diego de Queiroz Machado (UFC)

\section{ASSISTANT EDITORS}

Alane Siqueira Rocha (UFC)

Márcia Zabdiele Moreira (UFC)

\section{ASSOCIATE EDITORS}

Adriana Rodrigues Silva (IPSantarém, Portugal)

Alessandra de Sá Mello da Costa (PUC-Rio)

Andrew Beheregarai Finger (UFAL)

Armindo dos Santos de Sousa Teodósio (PUC-MG)

Brunno Fernandes da Silva Gaião (UEPB)

Carlos Enrique Carrasco Gutierrez (UCB)

Dalton Chaves Vilela Júnior (UFAM)

Elionor Farah Jreige Weffort (FECAP)

Gabriel Moreira Campos (UFES)

Guilherme Jonas Costa da Silva (UFU)

Henrique César Muzzio de Paiva Barroso (UFPE)

Jorge de Souza Bispo (UFBA)

Keysa Manuela Cunha de Mascena (UNIFOR)

Manuel Anibal Silva Portugal Vasconcelos Ferreira (UNINOVE)

Marcos Cohen (PUC-Rio)

Marcos Ferreira Santos (La Sabana, Colombia)

Mariluce Paes-de-Souza (UNIR)

Minelle Enéas da Silva (La Rochelle, France)

Pedro Jácome de Moura Jr. (UFPB)

Rafael Fernandes de Mesquita (IFPI)

Rosimeire Pimentel (UFES)

Sonia Maria da Silva Gomes (UFBA)

Susana Jorge (UC, Portugal)

Thiago Henrique Moreira Goes (UFPR)

\section{EDITORIAL BOARD}

Ana Sílvia Rocha Ipiranga (UECE)

Conceição de Maria Pinheiro Barros (UFC)

Danielle Augusto Peres (UFC)

Diego de Queiroz Machado (UFC)

Editinete André da Rocha Garcia (UFC)

Emerson Luís Lemos Marinho (UFC)

Eveline Barbosa Silva Carvalho (UFC)

Fátima Regina Ney Matos (ISMT, Portugal)

Mario Henrique Ogasavara (ESPM)

Paulo Rogério Faustino Matos (UFC)

Rodrigo Bandeira-de-Mello (FGV-EAESP)

Vasco Almeida (ISMT, Portugal)

\section{SCIENTIFIC EDITORIAL BOARD}

Alexandre Reis Graeml (UTFPR)

Augusto Cezar de Aquino Cabral (UFC)

Denise Del Pra Netto Machado (FURB)

Ednilson Bernardes (Georgia Southern University, USA)

Ely Laureano Paiva (FGV-EAESP)

Eugenio Ávila Pedrozo (UFRGS)

Francisco José da Costa (UFPB)

Isak Kruglianskas (FEA-USP)

José Antônio Puppim de Oliveira (UCL)

José Carlos Barbieri (FGV-EAESP)

José Carlos Lázaro da Silva Filho (UFC)

José Célio de Andrade (UFBA)

Luciana Marques Vieira (UNISINOS)

Luciano Barin-Cruz (HEC Montréal, Canada)

Luis Carlos Di Serio (FGV-EAESP)

Marcelle Colares Oliveira (UFC)

Maria Ceci Araujo Misoczky (UFRGS)

Mônica Cavalcanti Sá Abreu (UFC)

Mozar José de Brito (UFL)

Renata Giovinazzo Spers (FEA-USP)

Sandra Maria dos Santos (UFC)

Walter Bataglia (MACKENZIE) 